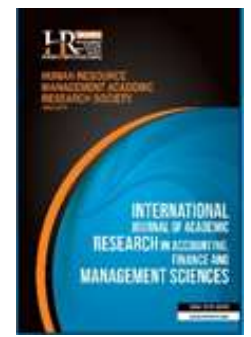

International Journal of Academic Research in Accounting, Finance and Management Sciences

Vol. 9, No.4, October 2019, pp. 294-303

E-ISSN: 2225-8329, P-ISSN: 2308-0337

(C) 2019 HRMARS

www.hrmars.com

To cite this article: Imagbe, V. U., Abiloro, T.O., Saheed, G.A. (2019). Fraud Diamond and Financial Crimes in Nigerian Banking Industries, International Journal of Academic Research in Accounting, Finance and Management Sciences 9 (4): 294-303

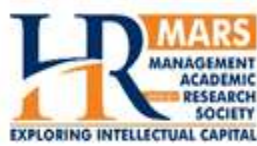

\title{
Fraud Diamond and Financial Crimes in Nigerian Banking Industries
}

\author{
V. U. Imagbe ${ }^{1}$, T. O. Abiloro', G. A. Saheed ${ }^{3}$ \\ ${ }^{1}$ University of Benin, Benin city, Edo state, Nigeria \\ ${ }^{2}$ Bursary Department, Rufus Giwa Polytechnic, Owo Ondo state, Nigeria, ${ }^{2}$ E-mail: tobanson316x@yahoo.com \\ ${ }^{3}$ Marketing Department, Rufus Giwa Polytechnic, Owo Ondo state, Nigeria
}

\begin{abstract}
This study examines the fraud diamond element as key determinants of financial crimes in Nigerian banking industries. Primary data were used for this study. This study was carried out by collecting data from 14 quoted commercial banks in Nigeria as at 31st December, 2018. The study utilized ordinary least square regression model. It was noted that the existence of fraud diamond elements which are pressure, opportunity, rationalization and capacity are the major factors that determines financial crimes in Nigeria banking industries. This indicates that an increase in the existence of all these variables will increase financial crimes in Nigeria banking sector. The study recommends a quick and significant attention to these key determinants of financial crimes through: the creation a culture of honesty, openness, and assistance; and also eliminating opportunities to commit fraud and creating expectations that fraud will be punished.

Key words Fraud Diamond, Pressure, Opportunity, Rationalization, Capability, Financial Crimes

Received: 09 Jan $2020 \quad$ (C) The Authors 2019

Revised: 19 Jan 2020 Published by Human Resource Management Academic Research Society (www.hrmars.com)

Accepted: 20 Jan 2020 This article is published under the Creative Commons Attribution (CC BY 4.0) license. Anyone may Published Online: $\quad 01$ Feb 2020 reproduce, distribute, translate and create derivative works of this article (for both commercial and non-commercial purposes), subject to full attribution to the original publication and authors. The full terms of this license may be seen at: http://creativecommons.org/licences/by/4.0/legalcode
\end{abstract}

\section{Introduction}

Financial crimes is viewed to have not only negative but damaging consequences on any nation's economy, security and social wellbeing of the general citizen. It is very necessary to note that as global and modern financial system encourages, facilitates both local and international commerce, antithetically, financial criminals are also evident through technology which enables transfer millions of dollars around the world instantly through available information communication infrastructures such as internet, electronic money transfer (wire transfer) and the rest which is referred to as "yahoo yahoo" in Nigeria (Okoye and Gbegi, 2013). There are numerous financial crimes like computer crime, identity theft, "yahoo yahoo", financial statement fraud, cash theft and money laundry and so on (Comer, 2008). Money laundry for example means making dirty money gotten from illicit activities clean by passing this dirty money through various financial institutions. In the case of Nigeria, money is laundered through currency exchange houses, stock brokerage houses, casinos, automobile dealership, and trading companies. These mentioned financial institutions and organizations are capable of concealing proceeds from illegal criminal activities, which in turn have an effect on the activities of the socio-political lives and economic wellbeing of the people leaving majorly in developing countries (Ribadu, 2004).

It is difficult to believe at times that developed countries also suffered from criminal manipulation of Company's statement of financial position which creates a much more robust and favorable picture about their finances than what is the reality through window dressing or creative accounting. This is evident in 
the case of Enron Company which unexpectedly went burst and which is probably the best known example of accounting books manipulation in recent times.

Okoye and Gbegi (2013) noted that in the United State of America, problem arose in the mortgage industry because during the booming period, investors enters market hoping for huge profit to be made on mortgages, which could be so unrealistic and unsustainable. However, it was noted that with time, there were massive defaults in payments leading to foreclosures; this caused chaos, doom and gloom in housing market. Since the world is a global village, investors in the business were world-wide; this financial crisis in the United State of America also had a transmitting effect on the world economy through financial crimes. This was also evident in Nigeria, sometimes ago the Lagos state government funds were trapped by these fraudsters.

Recently in Nigeria the most common types of financial crimes majorly in banks and agencies of government are: electronic banking fraud; ATM card fraud; Fraudulent transfer, Management fraud and withdrawals of funds; Use of unauthorized overdraft; Posting of fictitious credits; Presentation of forged cheques; Conversion of banks money into personal use; Granting of unauthorized loans; Abuse of medical scheme; Insider abuse; Illegal conversion of pension funds in various agencies and ministries; Ghost workers fraud resulting into millions of naira paid into private pockets; Abuse of political office leading to contract over billings and over invoicing; bribery; identity theft, mail fraud; bankruptcy fraud; wire fraud; advance fee fraud; paperhanging; kitting; stolen cheques; money laundering; embezzlement and so on (Economic and Financial Crimes Commission [EFCC], 2004). Comer (2008) stated that the possible motivation for these financial crimes includes: Personal greed; Possibility of getting away; Low prosecution rate; Societal pressures; High debt; Financial pressure; Staff morale problems; internal control weaknesses and Anti-institutional posture. Wolfe and Hermanson (2004); Gbegi and Adebisi (2013) noted that there are four conditions or elements that must be present before an act of fraud could be committed, among these are pressure, opportunity, rationalization and capability which is referred to as the fraud diamond.

Researches has been done on fraud and financial crime, in which so many conclusions has been drawn on the effect of fraud and financial crime in Nigeria economy and society at large, the results revealed a negative impact on the economic development. But no research as being done on looking at the real determinants of financial crimes in Nigeria through the consideration of fraud diamond elements, which are pressure, opportunity, rationalization and capacity. It is believed that once a problem is identified, there is already a clue to providing solution to such problem. Therefore, this research work tends examine the fraud diamond as a determinant factor to financial crimes in Nigerian Banking Industries.

\section{Literature review}

This study conducts an extensive survey of exiting literature on fraud diamond as a major determinant of financial crimes in Nigeria banking sector. This section cover the conceptual frame works, theoretical frame work and review prior empirical studies on financial crimes.

\subsection{Concept of Fraud}

Fraud as it is have different meaning to different people, therefore they tend to define it based of the circumstances, situations, observation, conclusion, organisation culture, academic view, legal perceptions personal experience and so on. Eseoghene (2010) defined fraud as an intentional act of deception that is aimed at getting an undue advantage at the expense of individual or organization loosing properties or some lawful rights. Black's law dictionary (2004) posited that fraud is the misrepresentation of the truth or concealment of a material fact to induce another to act to his or her detriment. In the broadcast sense, fraud can encompass any crime for crime for gain uses deception as its principle modus operators. Consequently fraud includes any intention or deliberate act that deprives another person of his/her property or money by guile, deception, or other unfair means. Fraud can be committed either internally by employees, managers, officers, or owners of the company, or externally by customers, vendors, and other related parties. Association of Certified Fraud Examiners [ACFE] (2012) defines fraud as "any illegal acts characterized by deceit, concealment, or violation of trust. These acts are not dependent upon the application of threat of violence or of physical force. Frauds are perpetrated by individuals and organisations to obtain money; or to secure personal or business advantage. Institute of Chartered 
Accountant of Nigeria [ICAN] (2006) noted that fraud consists of both the use of deception to obtain an unjust or illegal financial gain and intentional misrepresentation of fact, affecting the financial statement by the one or more persons among management or third party. Ruin (2009) also noted that fraud is collectively or individually committed with an intention to deriving undue advantages, avoiding obligation and therefore making another party to suffer both financial and non-financial loss.

The American Institute of Public Accountants (AICPA) (2002) defines fraud as "a broad legal concept that is distinguished from error depending on whether action is intentional or unintentional" they broke fraud down into different element and concluded that fraud can only be evident if the elements are present. These elements are as follows: A representation; that is material; which is false; it is intentionally or recklessly so; which is believed by a person; and acted upon by that person; the person suffer damage. Archibong (1992) sees fraud as a predator mined and well planned tried process or device usually undertaken by a person or group of persons, with the sole objective of cheating other persons or organization, to gain illegal advantage, be it monetary or otherwise which could not have acceded in the absence of such deceitful act.

Enofe et al. (2017) noted that fraud is a threat to any banking industry going concern because its existence can make the shareholders and connected stakeholders suffer a very high financial damage. They posited that fraud is not only peculiar to banking industry alone but affect every system as it was evident in multinational company like Enron, WorldCom and so on, whom fraud occurrence really affected their going concern negatively. They therefore concluded that if organisation must redeem their goodwill and good name, there is a need to establish an ethical guidelines and ethical codes in order to prevent fraudulent acts.

\subsection{Financial crimes}

The Economics and Financial Crime Commission Acts [EFCC] Act (2004) attempts to capture the variety of economic and financial crime found either within or outside issues in EFCC's (2004) illicit activities committed with the objective of earning wealth illegally in a manner that violates existing legislation and these include any form of fraud, narcotic drug, trafficking, money laundry, embezzlement, bribery, looting and any form of corrupt malpractices, illegal oil bunkering and illegal mining, tax evasion, foreign exchange malpractice including counterfeiting, currency theft of intellectual property and pricey, open market abuse, jumping of toxic. Waste and prohibited goods etc. this definition is all - embracing and conceivably include financial crimes in corporate organization and those discussed by provision Williams (2005).

International Monetary Fund [IMF] (2001) noted that there is no international acceptable definition for financial for financial crimes but it can be expressed in terms of jurisdiction and the context. In the broad sense, IMF defined financial crimes as any non-violent crime leading to a financial loss. IMF (2001) noted that when financial institution is involved, it is termed financial sector crime and that financial institutions are prone to financial crimes in three ways, which are as a: victim, perpetrator and instrumentality. Generally, financial crimes are varied and committed by individual, managements, governments and institutions. The one committed by the banking industry can be broadly regarded as corporate fraud. Yu (2013) defined corporate fraud as the misconduct or unethical behaviour committed by firms' or its manager which lead to shareholders or stakeholders suffering material financial loss that may lead to litigation process. Therefore, financial crimes in banking industry are specifically categorized into employee fraud and management fraud.

\subsection{Pressure and financial crimes}

Pressure is what causes or motivates a person to involve in fraudulent activities or financial crimes. This pressure can include almost anything including medical bills; children school fees, high level of debt, greed, expensive tastes, addiction problems etc. Most of the time, pressure comes from significant financial need/problem. Pressure has been measured in previous empirical studies using liquidity high debt and problem of financial performance. The studies in Wuerges and Borba (2010); Kirkos et al., (2007); and Beneish (1999) show that firms whom are highly geared or indebted are more likely to act illegally in other to cover up their company's position and thereby ensuring that the company move on. Perols and Lougee (2011) notes that the situation where a firm has low liquidity, they tend to get involved in the financial 
statements manipulations in order to deceive the shareholders and potential investors. Deehow, Ge, Larson and Sloan (2011); Okoye et al., (2009); Brazel et al., (2009); Summers and Sweeney (1998) notes that the quest to have an high level of performance or meeting up with a demand or target steers up pressure or what motivate an individual to result in nothing but committing a fraud. This is an indication and the reflection of the fact that having a low level of performance motivates managers to defraud the organisation by the way of increasing their results, hiding the problems and improving the overall performance of the company (Okoye, 2014).

\subsection{Opportunity and financial crimes}

This is the second important determinants of financial crimes. It can come as a result of ineffective or weak control or governance system which can give room for individual or organisation that have fraud intent to commit this crime. Kelly and Hartley (2010) suggested that people will always take any advantage to commit financial crimes if its' so made available for them and that financial crimes is more likely to be committed if there is lower risk of being caught. Shackell (2000) posited that some other factors that can contribute to the existence of financial crimes is the assumption that the employer is unaware, the assumption that the employee are not being checked regularly for the violation of organisations policies, the believe that no one will care and that no one will even consider such offence a serious one.

Opportunity is created by weak internal controls, poor management oversight, and/or through use of one's position and authority to overrides control, organisation's failure to establish effective and adequate procedures that mitigate and detect fraudulent activity has also increase the opportunities to commit financial crimes (Matoussi and Gharbi, 2011; Beasley and Carcello, 2000). They observed that the inclusion of a maximum of external members in the board of Directors can reduce the likelihood of fraud occurrence. Wilson (2007) while supporting this conclusion also pointed that opportunity is the ability to override fraud control that has being put in place by an organisation. Okoye et al. (2009) considering opportunities in falsified financial statements using the quality of external audit noted that the external auditors belonging to the big audit firms have some ability to detect falsified financial statements than non-big audit firms because of the experiences and skills they have gathered over the years and the ability to expose every loopholes which could serve as a deterrent to anyone who may wish to commit financial crimes.

\subsection{Rationalization and financial crimes}

Rationalization has the third key determinants of financial crimes suggests that people that commits financial crimes always formulate some type of morally acceptable justification before engaging in this unethical behaviour. An individual who cannot justify his acts of committing fraud might not likely commit the fraud. Wells (2005) noted that some typical examples of rationalization or excuses people give are: "I was only borrowing the money", "I had to steal to provide for my family need", "I was underpaid or my employer had cheated me", "everyone also does it", "everyone is getting rich, why shouldn't I?. Hooper and Pornelli (2010) observed that individuals who commit fraud always posses a particular notion or mindset that enables them to justify or give excuses for their unethical behavior. The lack of personal integrity or other moral reasoning is what makes an individual to justify or rationalize unethical behavior or fraudulent act (Rae and Subramanian, 2008). Rationalization is a crucial component in most frauds. Rationalization involves a person reconciling his/her behavior (stealing) with the commonly accepted notions of decency and trust. Rationalization may be measured using rotation of auditors.

\subsection{Capability and financial crimes}

An employee function or positions whether a supervisory role or management role may actually give an ability to commit fraud wish others that not in that position will not be able to commit. People that involve in financial crimes always posses that necessary skills, traits, technical know-how and abilities to commit the fraud, falsify appropriate documents and go away with it (Wolfe and Hermanson, 2004). Abdullahi et al., (2015) noted that many of the world large organisations has experienced major financial crimes, in which this financial crimes had a devastating effect on the global economy to the extent that it has increased global unemployment rate for the lower and middle level class of employee. This people suffered unemployment due to financial crimes committed by those at the top level or people whom their 
role or positions give them the capability to commit fraud. This means having the necessary, technical know-how, traits or skills and abilities to commit financial crimes. This is when a fraudster recognised the particular fraud opportunity and ability to turn it into reality. Wolfe and Hermanson (2004) noted that position, intelligence, ego, coercion, deceit and stress are six basic characteristics or traits that encourage this fourth element or the supporting elements of capability.

\subsection{The Fraud Diamond Theory}

Frauds diamond is an idea to investigate the causes of fraud. Reasons people commit fraud was first examined by Cressey Donald, a criminologist in 1950. The idea was coined by Donald Cressey (1973) called the fraud triangle or triangle cheating. His research was about what drives people to violate trust. He interviewed two hundred and fifty criminals whose behavior met two criteria: one, the person must have accepted a position of trust in good faith, and secondly the person must have violated the trust. In an attempt at explaining fraud in accounting, Cressey (1953) proposed the following function: FRAUD = $\mathrm{f}$ (Pressure, Opportunity, Rationalization). This was further re-modified by Wolfe and Hermanson (2004), whereby they deemed it fit to introduce the fourth elements after some criticisms which were "Capability". They were of the opinion that fraud would not have occurred if the person does not have the skills, technical know-how or the capability of carrying out such act. According to them, this capabilities for committing fraud centers on the person's being in a position of authority in government, organisation or any establishment; the confidence he/she had of not being caught and if otherwise caught that he/she would be released easily; the ability to understand, beat and manipulate the organisation's accounting system and internal control for personal gain.

Wolfe and Hermanson (2004) fraud diamond is presented in the diagram below:

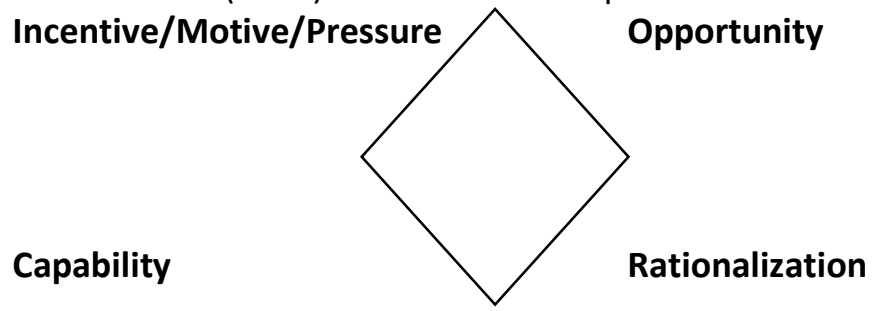

Source: Wolfe and Hermanson (2004)

Figure 1. Fraud diamond

\subsection{Empirical review}

There are many instances of both public and private companies, which have suffered loss due to financial crimes. This has led many researchers to undertake empirical studies on the area financial crimes. Many researcher studies the determinants of corporate crime activities in organizations in order to minimize the occurrence of fraud. Their findings indicate that the corporate crime determinants ranked by most of the respondents are insufficient control, followed by personal financial pressure and expensive lifestyle.

Said et al., (2017) examines integrating ethical values into fraud triangle theory in assessing employee fraud, taken evidence from the Malaysian banking industry, they collected primary data from 108 questionnaires that were administered to the employees of the top three leading banks in Malaysia. Their findings show that ethical values is having a negative relationship with employee fraud, which the three elements of the fraud triangle namely pressure, opportunity and rationalization are positively related. This is an indication that ethical values reduce financial crimes while they recommended that organisation must block every loophole in order to minimize fraud occurrence.

Gamlath et al., (2018) carry out study on the new fraud triangle theory-integrating ethical values of employees. They found that lack of ethical values such as integrity is what leads to continuous financial crimes. They conclude that it is of great importance for auditors and forensic accountants to observe all fraud models and have the knowledge of how fraud is being perpetrated. They further explained their stand by introducing a new fraud model that incorporates ethical values because they have seen that high level of ethical values of the employees is likely to reduce financial crimes. 
Mathenge (2014) examines empirical study to measuring corruption and integrity in Kenyan police agency. They found that high ethical values which are noted to be technical competence, confidentiality and high level of professionalism will definitely reduce the likelihood of financial crimes in an organisation.

Amara et al. (2013) examine detection of fraud in financial statements. More specifically, they found that the performance of issue exerted on the manager is a factor of pressure leading to commit fraud in the financial statements. However, factors related to financial difficulties (debt, liquidity) and the size of auditing firm are not associated with the detection of fraud Okoye and Gbegi (2013) observed that fraud and related financial crime have no significant effect on inflation.

\section{Methodology of research}

This study employed survey method of research design. The choice of this design is because it offers the researcher the opportunity to generate a large volume of data from different organization and institutions, thereby providing a valid generation of research findings (Akenbor and Okoye, 2012). The source of getting data for this study was mainly primary source through the use of structured questionnaire. The population of the study was made up staff all 14 commercial Banks listed on Nigerian stock exchange (NSE) as at December 2018, their Directors/Finance Managers, Branch Managers and Operations Managers, Compliance officers, Head of different units and Customers service officer will be the respondents, also some other staffs based on their experience and knowledge of banking activities and some customers who were met at each branch. A branch of each of these quoted banks was chosen in Ondo State Nigeria to represent the entire branch in Nigeria. The choice of this technique is that it provides equal probability of selection and also minimizes selection bias. The target respondents of the study were selected using purposive sampling. This is to ensure that only knowledgeable respondents were chosen. The study adopted descriptive statistics and Ordinary Least Squares (OLS) regression as a method of data analysis.

\subsection{Model Specification}

The dependent variable for this study will be Financial Crimes (FIC). The independent variables are Pressure (PRE), Opportunity (OPP), Rationalization (RAT), and Capability (CAP).

The following model is specified in accordance with the objective and formulated hypothesis in other to guide and capture the effect of independents variable on dependent variable on this study:

$\mathrm{FIC}=\mathrm{f}(\mathrm{PRE}, \mathrm{OPP}, \mathrm{RAT}, \mathrm{CAP})$

$\mathrm{FIC}_{\mathrm{t}}=\beta_{\mathrm{o}}+\beta_{1} \mathrm{PRE}_{\mathrm{t}}+\beta_{2} \mathrm{OPP}_{\mathrm{t}}+\beta_{2} \mathrm{RAT}_{\mathrm{t}}+\beta_{4} \mathrm{CAP}_{\mathrm{t}}+\mathrm{U}_{\mathrm{t}}$

Where:

FIC = Financial Crimes

$\mathrm{PRE}=$ Pressure

$\mathrm{OPP}=$ Opportunity

RAT $=$ Rationalization

CAP= Capability

$\mathrm{U}=$ Error Term

Table 1. Measurement of Variables

\begin{tabular}{|c|c|l|c|c|}
\hline S/N & VARIABLES & \multicolumn{1}{|c|}{ OPERATIONAL DEFINITION } & SOURCE & Apriori Sign \\
\hline 1 & $\begin{array}{c}\text { Financial } \\
\text { Crimes }\end{array}$ & $\begin{array}{l}\text { Ten items in the questionnaire will be } \\
\text { designed to measure the level of financial } \\
\text { crimes. }\end{array}$ & $\begin{array}{c}\text { Wilson (2004); Holtfrefer } \\
\text { (2004) }\end{array}$ & -ve \\
\hline 2 & Pressure & $\begin{array}{l}\text { Ten items in the questionnaire will be } \\
\text { designed to measure the extent at which } \\
\text { pressure (both financial and non-financial } \\
\text { pressure) affects financial crimes. }\end{array}$ & $\begin{array}{c}\text { Razaee (2005); Dellaportas } \\
\text { (2013). }\end{array}$ & + +ve \\
\hline 3 & Opportunity & $\begin{array}{l}\text { Ten items in the questionnaire will be } \\
\text { designed to measure the level of weakness }\end{array}$ & $\begin{array}{c}\text { Din (2008); Wolfe and } \\
\text { Hermanson (2004) }\end{array}$ & + +ve \\
\hline
\end{tabular}




\begin{tabular}{|c|c|l|l|c|}
\hline S/N & VARIABLES & \multicolumn{1}{|c|}{ OPERATIONAL DEFINITION } & SOURCE & Apriori Sign \\
\hline & & $\begin{array}{l}\text { in their working environment that could } \\
\text { create opportunities for financial crimes. }\end{array}$ & & \\
\hline 4 & Rationalization & $\begin{array}{l}\text { Ten items in the questionnaire will be } \\
\text { developed on rationalization to reflect the } \\
\text { working conditions and working } \\
\text { environment that give room for justification } \\
\text { of unethical behaviour. }\end{array}$ & Marquet (2011); Tugas (2012). & + +ve \\
\hline 5 & Capability & $\begin{array}{l}\text { Ten items in the questionnaire will be } \\
\text { designed to measure the extent at which } \\
\text { capability (the required skills or technical } \\
\text { know-how) affects financial crimes. }\end{array}$ & $\begin{array}{l}\text { Wolfe and Hermanson (2004); } \\
\text { Gbegi and Adebisi (2013) }\end{array}$ & + +ve \\
\hline
\end{tabular}

\subsection{Data analysis and interpretation of results}

Table 2. Descriptive Statistics

\begin{tabular}{|l|c|c|c|c|c|c|}
\hline & N & Range & Mean & Std. Deviation & Skewness & Kurtosis \\
\cline { 2 - 7 } & 84 & 4 & 2.36 & 1.004 & 0.105 & -1.029 \\
\hline PIC & 84 & 4 & 2.46 & 1.002 & 0.062 & -1.110 \\
\hline OPP & 84 & 4 & 2.39 & 1.014 & 0.104 & -1.038 \\
\hline RAT & 84 & 4 & 2.34 & 1.026 & 0.110 & -1.160 \\
\hline CAP & 84 & 4 & 2.28 & 1.031 & 0.102 & -1.102 \\
\hline Valid N (list wise) & 84 & & & & & \\
\hline
\end{tabular}

Source: SPSS Version 20.0

\section{Statistic (Table 2)}

The descriptive statistics of the variables used in the analysis as presented in table 2 explains the range, mean, standard deviation and the normality of variables, financial crimes is the main variable of interest, which is the dependent variable. From the table financial crimes had a mean value of 2.36 and the standard deviation is 1.004 which is a little close to the mean, this shows a low degree of variability of data. Financial crimes were positively skewed with a skewed value of 0.105 which shows it is normally distributed. All the explanatory variables are positively skewed which are Pressure (PRE), Opportunity (OPP), Rationalization (RAT), and Capability (CAP).

Table 3.The Computation of (OLS) Result

\begin{tabular}{|c|c|c|c|c|}
\hline Variables & Coefficient & Standard error. & T-statistics & Probability \\
\hline Intercept & 3.574 & 0.247 & 8.968 & 0.000 \\
\hline PRE & 2.165 & 0.120 & 3.865 & 0.017 \\
\hline OPP & 1.242 & 0.257 & 3.876 & 0.002 \\
\hline RAT & 2.636 & 0.456 & 8.465 & 0.004 \\
\hline CAP & 2.254 & 0.432 & 4.256 & 0.028 \\
\hline $\begin{array}{l}\left.R^{2}=0.682, R^{2} \text { bar }=0.634, \text { F-stat., (4,84)=31.172, Pro(F-stat., }\right)=0.000 \\
\text { D.W }=2.131\end{array}$
\end{tabular}

Source: SPSS Version 20.0

\section{OLS Analysis (Table 3)}

$\mathrm{FIC}=3.574+2.165+1.242+2.636+2.254+\mathrm{U}$

S.E $=\left(\begin{array}{llll}(0.247) & (0.120) & (0.257) & (0.456)(0.432)\end{array}\right.$

T-Stat $=\{8.968\}\{3.865\}\{3.876\}\{8.465\}\{4.256\}$

The intercept value shows 3.574 which means Financial Crimes (FIC) has 3.574 units when other variables are held constant. Pressure (PRE) shows that one percentage increase in employee pressure will bring 2.165 percent increases in financial crimes, and this is significant at 0.017 , because it is less than 0.05 level of significance. Opportunity (OPP) shows that one percent increase in opportunity to commit fraud will bring 1.242 percent increases in the financial crimes; it is also significant at 0.002, because it is less than 
0.05 level of significance. Rationalization (RAT) shows that one percent increase in the justifications for committing fraud will bring 2.636 percent increases in financial crimes; it is also significant at 0.004 , because it is less than 0.05 level of significance. Capability (CAP) shows that one percent increase in the required skills for committing fraud will bring 2.636 percent increases in financial crimes; it is also significant at 0.004 , because it is less than 0.05 level of significance.

The R-squared stand at 0.682 which shows the explanatory power of the model which can be seen as $68.2 \%$, means $68.2 \%$ of changes in fraud prevention can be explained living $31.8 \%$ unaccounted for. The $F-$ statistic shows the robustness of the model by comparing F-calculated to F-critical in order to explain the impact of whole explanatory variables on explained variable, and this was shown by looking at it from the angle of 0.01 and 0.05 level of significance which are 3.78 and 2.60 and are less than 31.172 calculated respectively, in terms of overall significance all independent variables showed a significant relationship with the dependent variable with the prob. (F-statistic) of 0.000 . The Durbin Watson value of 2.131 is an indication of the absence of autocorrelation in the model.

\section{Discussion of findings}

Based on the OLS table above, the result shows about $68.2 \%$ of the systematic variation in BFP is explained by four independent variables (PRE, OPP, RAT and CAP). This coefficient determination is strong and shows a good fit of the regression line as well as indicating the forecasting power of the model is strong. The $F$ value of 31.172 is statistically significant at $5 \%$. This means that PRE, OPP, RAT, CAP have significant positive relationship with FIC. The results from the analyses above are indications that the independent variables have a significant impact on the financial crimes in Nigerian Banking industries. This reveals that if nothing is done to curb or reduce the existence of fraud diamond elements which are pressure (Financial and Non-Financial pressure), opportunity (weaknesses in the control system), Rationalization (justifications for committing fraud) and capability (required skills or technical know-how), financial crimes will continue to linger within banking institutions in Nigeria. Literature is filled to satisfaction with a very wide range benefits these variables offers its adopters.

\section{Conclusion and recommendations}

This study examined the key determinants of financial crimes in Nigeria banking industries by considering fraud diamond elements (i.e. Pressure, Opportunity, Rationalization and Capacity). The study finds a positive and significant relationship between these fraud diamond elements and financial crimes in Nigeria banking industry. This is an indication that if organisation won't take appropriate measures towards curbing or reducing the effect of these elements within their organisation, they are prone to financial crimes.

The study recommends a quick and significant attention to these key determinants of financial crimes through: the creation a culture of honesty, openness, and assistance; and also eliminating opportunities to commit fraud and creating expectations that fraud will be punished. This can be done by considering the following: hiring honest people and providing fraud awareness training; creating a positive work environment, which means having a well-defined code of conduct, having an open-door policy, not operating on a crisis basis, and having a low-fraud atmosphere; providing an employee assistance program (EAP) that helps employees deal with personal pressures; having good internal controls; discouraging collusion between employees and customers or vendors and clearly informing vendors and other outside contacts of the company's policies against fraud; monitoring employees and providing a hotline (whistleblowing system) for anonymous tips; creating an expectation of punishment; and conducting proactive auditing.

\section{References}

1. Abdullahi, R., Mansor, N., \& Nuhu, M. S. (2015). Fraud Triangle Theory and Fraud Diamond Theory: Understanding the Convergent and Divergent for Future Research. European Journal of Business and Management, $7(28)$.

2. Akendor, C. O., \& Okoye, E. I. (2013). The adoption of strategic management accounting in Nigerian manufacturing firm. International Journal of Arts and Humanities, 1(3), 270-287. 
3. Amara, I., Amar, A. B., \& Jarboui, A. (2013). Detection of Fraud in Financial Statements; French companion as a case study. International of Academic Research in Accounting, Finance and Management Science, 3(3), $40-51$.

4. American Institute of Certified Public Accountant [AICPA] (2002). Consideration of fraud in a financial statement audit. Retrieved from https://www.aicpa.org/Research/Standards/AuditAttest/ DownloadableDocuments/AU-00316.pdf.

5. Arhibong, E. E. (1992). The Bank Inspectors Lib. New Born Publishers.

6. Association of Certified Fraud Examiners [ACFE]. (2012). Report to the Nations. Available at: http://www.acfe.com/rttn.aspx.

7. Beasley, M. S., Carcello, J. V., Hermanson, D. R., \& Lapides, P. D. (2000). Fraudulent financial reporting: Considerations of industrial traits and corporate governance mechanisms. Accounting Horizons, 14(4), $441-454$.

8. Bencish, M. (1999). The detection of earnings manipulation. Financial Analysts Journals, 6 (1), 24 36.

9. Brazel, J., Jones, K., \& Zimbelman, F. (2009). What can nonfinancial measures tell us about the likelihood of fraud? Accounting Research Symposilim, 9(1), 43-62.

10.Comer, M. (2008). Corporate fraud: Nature, typologies and essential theories. A paper delivered by B.I.G. consulting in conjunction with Association of National Accountants of Nigeria (ANAN) Ikeja Branch at Tourist Garden Hotel, Awka, June 4th - 6th, 2016.

11.Cressey, D. (1973). Other people's money. Montclair UK: Patterson Smith.

12.Davis, M. A., Andersen, M. G., \& Curtis, M. B. (2001). Measuring ethical ideology in business ethics: A critical analysis of the ethics position questionnaire. Journal of Business Ethics, 32(1), 35-53.

13.Deehow, P., Ge, W., Larson, C.R., \& Sloan, R.G. (2011). Predicting material accounting misstatement. Contemporary Accounting Research, 28 (1), 17-82

14.Dellaportas, S. (2013). Conversations with inmate accountants: Motivation, opportunity and the fraud triangle. Accounting Forum, 37(1), 29-39.

15.Din, H. F. M. (2008). Survey on the Use of Fraud Risk Red Flags by Auditors Financial Crimology. Master Dissertation, Accounting Research Institute, Universiti Tekmologi MARA.

16.Economic and Financial Crime Commission [EFCC]. (2004). Section 46 of the EFCC Act, 2004.

17.Enofe, A. O., Abilogun, T. O., Omoolorun, A. J., \& Elaiho, E. M. (2017). Bank fraud and preventive measures in Nigeria: An empirical review. International Journal of Academic Research in Business and Social Sciences, 7(7), 40-51.

18.Eseoghene, J. I. (2010). Bank frauds in Nigeria: Underlying causes, effects and possible remedies. African Journal of Accounting, Finance and Banking Research, 6(6), $62-80$.

19.Gamlath, M. M., Mohd, S. A., Ali., K., Ferdous, A., \& Isuri, D. (2018). The new fraud triangle theoryintegrating ethical values of employees. International Journal of Business, economics and law, 16(5), 52-57.

20.Gbegi, D. O., \& Adebisi, J. F. (2013). The New Fraud Diamond Model - How can it help forensic accountants in fraud investigation in Nigeria? European Journal of Accounting Auditing and Fiancé Research 1, (4), 129-138.

21. Hooper, M. J., \& Pornelli, C. M. (2010). Deterring and detecting financial fraud: A platform for action. Retrieved from http://www.thecaq.org/docs/reports-and-publications/deterring-and-detecting financial-reporting-fraud-aplatform-for-action.pdf?

22. Holtfreter, K. (2004). Fraud in US organisations: An examination of control mechanism. Journal of Financial Crime, 12(1) 88-95.

23. Institute of Chartered Accountant of Nigeria [ICAN] (2006). Financial Reporting and audit practice. ICAN PACK.

24.International Monetary Fund [IMF] (2001). Financial system abuse, financial crime and money laundering - background paper. Paper prepared by the monetary and exchange affairs and policy development and review department. Retrieved from https://www.imf.org.

25.Kelly, P., \& Hartley, C. A. (2010). Casino gambling and workplace fraud: a cautionary tale for managers. Management Research Review, 33(3), 224-239. 
26.Kirkos, E., Spathis, C., \& Manolopoulos, Y. (2007). Data mining techniques for the detection of fraudulent financial statements. Expert systems with Applications, 32 (4), 995 - 1003.

27. Marquet, C. T. (2011). The top 10 embezzlement cases in modern US history. Retrieved from http://www.marquetinternational.com/pdf/top_10_embezzlement_cases_in_us_history.pdf.

28. Mathenge, G.D. (2014). An empirical study to measuring corruption and integrity in Kenyan police agency: An ethical perspective. Public Policy and Administration Research, 4(2), 67-79.

29.Matoussi, H., \& Gharbi, I. (2011). Board independence and corporate fraud: the case of Tunisian Firms. Politics and Economic Development Journal, 1(6), 23-31.

30.Okoye, E. I., \& Gbegi, D. O. (2013). An Evaluation of the effect of fraud and related financial crimes on the Nigeria economy. Kuwait chapter of Arabian Journal of Business and Management Review. 2 (7), 81 -91 .

31.Okoye, A. F. (2014). Detecting falsified financial statements: Application of data mining techniques. Phd Seminar Paper.

32.Okoye, E., Okafor, T., \& ljeoma, N. (2009). Impact of the fraud triangle on audit process, the Nigerian Accountants' View. The University Advanced Research Journal,1(11), 9 - 15

33.Okoye, E., Ukenna, S., \& Ugwanyi, U. (2009). Understanding and explaining the underpinnings of creative accounting in Nigeria: the Cadbury evidence. Certified National Accountants 17 (1), 31.

34.Perols, J., \& Lougee, B. (2011). The relation between earnings management and financial statement fraud, Advances in Accounting, incorporating Advances in International Accounting, 27, $39-53$.

35.Rae, K., \& Subramaniam, N. (2008). Quality of internal control procedures: Antecedents and moderating effect on organisational justice and employee fraud. Managerial Auditing Journal, 23(2), 104124.

36.Rezaee, Z. (2005). Causes, consequences, and deterence of financial statement fraud. Critical Perspectives on Accounting, 16(1), 277-298.

37.Ribadu, N. (2004). The role of EFCC in sanitizing the Nigeria economic environment in a democratic setting. Being a Paper presented at the Adamawa state, Nigeria. Economic Conference and Financial Exhibition, December $9-10$.

38.Ruin, J. E. (2009). Internal auditing: Supporting risk management, fraud awareness management and Corporate Governance. Leeads Publication.

39.Said, J., Alam, M. M., Ramli, M., \& Rafidi, M. (2017). Integrating ethical values into fraud triangle theory in assessing employee fraud: Evidence from Malaysian banking industry. Journal of International Studies, 10(2), 170-184.

40.Shackell, M. P (2000). Corporate Fraud prevention, detection and investigation; A practical guide of dealing with corporate fraud. Australia, Prize Water House coopers.

41.Summers, S., \& Sweeney, J. (1998). Fraudulently misstated financial statements and insider trading. An empirical analysis. The Accounting review, 73 (1) $131-146$.

42.Tugas, F. C. (2012). Exploring a new element of fraud: A study on selected financial accounting fraud cases in the world. American International Journal of Contemporary Research, 2(6), 112-121.

43.Wells, J. T. (2005). Principles of fraud examination. Hoboken, N. J. : John Wiley \& Sons Inc.

44.Wilson, I. (2007). Regulatory and institutional challenges of corporate governance in Nigeria post consolidation. Nigerian Economic Summit Group (NESG) Economic Indicators, April-June, 12 (2).

45.Wilson, R. A. (2004). Employee dishonesty: National survey of risk managers on crime. Journal of Economic Crime Management, 2(1), 1-25.

46.Wolfe, D., \& Hermanson, D. R. (2004). The fraud diamond: Considering four elements of fraud. The CPA Journal, 74(12), 38-42.

47.Wuerges, A., \& Borba, J. (2010). Accounting Fraud detection: is it possible to quantity undiscovered cases? Social Science Research Network. Retrieved from http:/ssrn.com/abstract=1718652.

48.Yu, X. (2013). Securities fraud and corporate finance: Recent Development. Managerial Decision and Economics, 34(1), 439-450. 